\title{
Perbedaan Pencacahan Daun Cengkeh Varietas Zanzibar (Syzgium aromaticum L.) Terhadap Hasil Minyak Atsiri
}

\author{
Author(s): Rochmathul Ummah ${ }^{(1)}$; Lilik Mastuti $^{(1)^{*}}$; Siti Humaida ${ }^{(1)}$ \\ (1) Jurusan Produksi Pertanian, Politeknik Negeri Jember \\ * Corresponding author: lilik_mastuti@polije.ac.id
}

\author{
Submitted: 26 Sep $2019 \quad$ Revised: 25 Mar $2020 \quad$ Accepted: 26 Mar 2020
}

\begin{abstract}
ABSTRAK
Limbah daun cengkeh berlimpah dan telah dimanfaatkan menjadi minyak. Minyak daun cengkeh adalah salah satu produk minyak atsiri unggulan di Indonesia dan kebutuhan minyak daun cengkeh terus meningkat setiap tahun. Tetapi seringkali rendemen minyak yang dihasilkan rendah. Perbedaan pencacahan daun cengkeh merupakan alternatif untuk meningkatkan rendemen minyak. Tujuan dari penelitian ini adalah mengetahui pengaruh dari perbedaan pencacahan daun cengkeh terhadap hasil minyak atsiri dan mencari perlakuan terbaik dalam menghasilkan rendemen minyak tertinggi. Penelitian ini dilaksanakan di Unit Pelaksana Teknis Pakan dan Laboratorium Alat dan Mesin Pertanian Politeknik Negeri Jember. Dilaksanakan dengan menggunakan metode Rancangan Acak Kelompok (RAK) non faktorial. Faktor yang digunakan yaitu perbedaan pencacahan dengan 3 taraf perlakuan yang terdiri dari daun utuh (P1), cacahan besar (P2), cacahan kecil (P3) dan 9 ulangan menggunakan penyulingan uap dan air. Hasil penelitian menunjukkan bahwa perlakuan perbedaan pencacahan berpengaruh sangat nyata terhadap hasil minyak atsiri pada parameter kuantitatif. Pada parameter kualitatif, perbedaan pencacahan menghasilkan rendemen bahan tertinggi yaitu cacahan kecil, warna minyak yang banyak dihasilkan adalah cokelat kekuningan dan kuning kecokelatan, serta kadar eugenol semua perlakuan sesuai SNI. Eugenol tertinggi adalah perlakuan daun utuh. Perlakuan terbaik untuk menghasilkan rendemen minyak tertinggi adalah perlakuan dengan cacahan kecil.
\end{abstract}

\section{Kata Kunci:}

Minyak atsiri;

Pencacahan daun;

Varietas

zanzibar;

Keywords: $\quad$ The abundant waste of clove leaves has been used for oil production. The clove leaves

Cutting on

leave; oil is one of the quality essential oil production in Indonesia, and the demand is increase every year. However, the production is very low. The difference of the cutting on the clove leaves is an alternative for increasing the oil yield. The objective of this research is to find out the effect of the cutting on the result of essential oil and to find out the best

essential oil; treatment to generate the highest yield. This research is conducted at Technical Unit of

zanzibar Food and Agriculture tool and machinery Laboratory of Polytechnic of Jember. This variety; research is conducted using non-factorial Randomized Block Design. The factor to be used are the difference cutting by using 3 stages of treatment that covers full leaves (P1), big cut (P2), and small cut (P3) and 9 repeatition by using water and steam distillation. The results showed that the treatment affect significantly on the essential oil at the quantitative parameter. Regarding qualitative parameter, the difference of the cutting that generates the highest material yield is the small cut, while the color of oil that is mostly produced is yellowish brown and brownish yellow and the highest eugenol is generated by the full leave treatment. The best treatment to generate the highest oil yield is the treatment using small cut. 


\section{PENDAHULUAN}

Minyak daun cengkeh adalah salah satu produk minyak atsiri unggulan di Indonesia. Menurut Direktorat Jenderal Perkebunan (2016) luas areal tanaman cengkeh (Syzgium aromaticum L.) di Indonesia pada tahun 2017 menurut data Statistik Perkebunan Indonesia adalah 329.514 ha. Diperkirakan 2.368.043 ton/tahun potensi daun cengkeh gugur dari area tanam \pm 400.000 ha (Bustaman, 2011).

Menurut Rukmana and Herdi (2016) rata-rata daun kering dihasilkan 0,45-0,88 $\mathrm{kg} /$ pohon/minggu. Kandungan minyak atsiri pada pada daun cengkeh sebesar 1$4 \%$ dengan kandungan eugenol sebesar 70 $80 \%$. Salah satu varietas cengkeh adalah Varietas Zanzibar. Varietas ini dianjurkan untuk ditanam petani karena daya produksi relatif tinggi dengan tingkat adaptasi yang luas dibandingkan dengan varietas lainnya. Keadaan lingkungan yang sesuai karena tanaman cengkeh (Syzgium aromaticum L.) termasuk tanaman tropis membuat tanaman cengkeh tumbuh subur di Indonesia dan ketersediaan bahan baku daun cengkeh untuk diolah menjadi minyak yaitu daun cengkeh Varietas Zanzibar melimpah.

Swasembada cengkeh yang dinyatakan tercapai pada tahun 1991 membuat terjadinya penurunan harga cengkeh di pasaran Indonesia karena melewati target. Pemerintah ikut serta untuk mengatasi penurunan harga dengan beberapa cara, salah satunya yaitu diversifikasi atau penganekaragaman hasil. Minyak daun cengkeh merupakan salah satu diversifikasi produk cengkeh yang diharapkan mampu meningkatkan dan mensejahterakan petani cengkeh beserta keluarganya.

Minyak daun cengkeh tidak dimanfaatkan dalam industri farmasi saja, tetapi dimanfaatkan oleh industri makanan, minuman, rokok, kecantikan, kemasan aktif, pestisida nabati, dan industri kimia lainnya. Minyak daun cengkeh dengan komponen utama kandungan eugenol menentukan kualitas dan mutu minyak daun cengkeh tersebut. Kebutuhan minyak daun cengkeh akan terus meningkat seiring dengan kebutuhan dan pemanfaatan minyak daun cengkeh yang semakin beragam.

Tetapi seringkali rendemen yang dihasilkan dari minyak daun cengkeh tersebut rendah. Beberapa masalah yang ada pada saat penyulingan adalah minyak atsiri yang terperangkap/masih ada dalam jaringan tanaman sehingga menurunkan rendemen minyak atsiri (yield).

Perlakuan awal atau pre-treatment salah satunya dengan cara pencacahan. Hal ini dilakukan karena minyak atsiri dalam tanaman aromatik dikelilingi oleh pembuluh, rambut grandular, kelenjar minyak, dan kantung minyak atau memudahkan pengambilan minyak. Bila bahan yang akan dilakukan penyulingan dibiarkan utuh, minyak atsiri akan berhasil diekstraksi atau keluar apabila uap air mampu melewati jaringan tanaman dan mendorong ke permukaan. Sehingga perlu dilakukan pencacahan agar kelenjar minyak terbuka sebanyak mungkin (Guenther, 1990).

Penelitian terdahulu yang dilakukan oleh Perdana, Musthofa dan Yusuf (2015) menghasilkan rendemen tertinggi dari perlakuan cacahan kasar daun cengkeh (Tidak lolos ayakan 12 mesh) sebesar $0,752 \%$ sedangkan rendemen terendah adalah perlakuan daun cengkeh tanpa cacahan sebesar $0,165 \%$. Berdasarkan permasalahan tersebut dan dari penelitian terdahulu, maka dilaksanakan penelitian dengan mengganti ukuran ayakan menjadi 4 mesh yang diharapkan mampu meningkatkan rendemen minyak daun cengkeh secara maksimal serta mengetahui hasil minyak dari pencacahan daun yang akan disuling antara daun utuh, daun cacahan besar, dan daun cacahan kecil. 


\section{BAHAN DAN METODE}

Pelaksanaan penelitian perbedaan pencacahan daun cengkeh (Syzgium aromaticum L.) Varietas Zanzibar terhadap hasil minyak atsiri dilaksanakan di Unit Pelaksana Teknis Pakan dan Laboratorium Alat dan Mesin Pertanian Politeknik Negeri Jember.

Alat yang digunakan dalam penelitian adalah alat penyulingan uap dan air (Water and Steam Distilation), termohigrometer, jimo disk mill head tipe FFC-23, ayakan 4 mesh, oven listrik, cawan porselen, desikator, timbangan analitik, kompor LPG, tabung gas LPG, gelas ukur, separator, corong kaca, tabung reaksi, rak tabung reaksi, stopwatch, timbangan duduk, dan GC (Gas Chromatography).

Bahan yang digunakan dalam penelitian adalah daun cengkeh yang sudah gugur, air, karung plastik, terpal plastik, gas LPG, botol kaca, kertas label, dan alat tulis. Dilaksanakan dengan menggunakan metode Rancangan Acak Kelompok (RAK) non faktorial. Faktor yang digunakan yaitu perbedaan pencacahan terhadap hasil minyak atsiri dengan 3 taraf perlakuan. Perlakuan pencacahan terdiri dari (P1) Tanpa pencacahan (Daun utuh), (P2) Daun cacahan besar (Tidak lolos ayakan 4 mesh), (P3) Daun cacahan kecil (Lolos ayakan 4 mesh).

Perlakuan diulangi hingga 9 kali sehingga didapatkan 27 unit percobaan. Data hasil penelitian diolah secara statistik dengan sidik ragam atau menggunakan Analysis Of Variance (ANOVA) taraf 5\% dan $1 \%$. Apabila terdapat beda nyata maka dilanjutkan dengan uji Kontras Ortogonal.

Parameter pengamatan terdiri dari parameter kualitatif dan parameter kuantitatif. Parameter kualitatif terdiri dari rendemen bahan, warna minyak, dan kadar eugenol minyak. Sedangkan parameter kuantitatif terdiri dari kadar air bahan, volume minyak, berat minyak, dan rendemen minyak.

\section{HASIL DAN PEMBAHASAN}

Uji Kualitatif

Tabel 1. Rekapitulasi Hasil Rata-Rata Parameter Kualitatif

Table 1. The Recapitulation of Average Result Qualitative Parameters

\begin{tabular}{|c|c|c|c|}
\hline \multirow{2}{*}{$\begin{array}{l}\text { Parameter } \\
\text { Parameter }\end{array}$} & \multicolumn{3}{|c|}{$\begin{array}{c}\text { Perlakuan } \\
\text { Treatment }\end{array}$} \\
\hline & $\begin{array}{l}\text { Daun Utuh } \\
\text { Full Leaves }\end{array}$ & $\begin{array}{l}\text { Cacahan Besar } \\
\text { Big Cut }\end{array}$ & $\begin{array}{l}\text { Cacahan Kecil } \\
\text { Small Cut }\end{array}$ \\
\hline $\begin{array}{l}\text { Rendemen Bahan } \\
\text { Material Yield }\end{array}$ & $100 \%$ & $61,67 \%$ & $65,28 \%$ \\
\hline $\begin{array}{l}\text { Warna } \\
\text { Color }\end{array}$ & $\begin{array}{l}\text { Cokelat Kekuningan } \\
\text { dan Kuning } \\
\text { Kecoklatan } \\
\text { Yellowish Brown and } \\
\text { Brownish Yellow }\end{array}$ & $\begin{array}{l}\text { Cokelat Kekuningan } \\
\text { Yellowish Brown }\end{array}$ & $\begin{array}{l}\text { Cokelat Kekuningan } \\
\text { Yellowish Brown }\end{array}$ \\
\hline $\begin{array}{l}\text { Kadar Eugenol } \\
\text { Eugenol Degree }\end{array}$ & $85,76 \%$ & $83,54 \%$ & $82,17 \%$ \\
\hline
\end{tabular}

\section{Rendemen Bahan}

Pencacahan bahan bertujuan untuk mempersiapkan bahan yang akan dilakukan penyulingan serta mempermudah keluarnya minyak atsiri dari dalam ruang antar sel dalam jaringan yang ada pada kantung minyak daun cengkeh. Pencacahan dilakukan dengan masing-masing ulangan sebesar $2 \mathrm{~kg}$. Cacahan besar dilakukan pencacahan menggunakan mesin sebanyak 2 kali pencacahan pada masing-masing ulangan 
dan pengulangan pencacahan atau sebanyak 3 kali pencacahan pada masingmasing ulangan untuk perlakuan cacahan kecil. Setelah dilakukan pencacahan dilanjutkan dengan pengayakan menggunakan ayakan 4 mesh. Pengertian dari 4 mesh adalah terdapat 4 lubang pada bidang jaring seluas 1 inch persegi (1 lubang $=1,27 \mathrm{~cm}^{2}$ ).

Tabel 2. Hasil Pencacahan Daun Cengkeh Perlakuan Cacahan Besar dengan 2 Kali Pencacahan

Table 2. The Result of The Cutting on Clove Leaves of Big Cut Leaves Treatment With Twice Cutting

\begin{tabular}{ccc} 
Cacahan & Rendemen \\
Yutting & $\begin{array}{c}\text { Total } \\
\text { Kehilangan } \\
\text { Total of } \\
\text { Loss }\end{array}$ \\
\hline $\begin{array}{c}\text { Besar } \\
\text { Big }\end{array}$ & $61,67 \%$ & $3,33 \%$ \\
Kecil & $35 \%$ & \\
Small & & \\
\hline
\end{tabular}

Waktu yang dibutuhkan untuk mencacah pada perlakuan cacahan besar adalah 12,19 menit dan waktu yang dibutuhkan untuk mengayak pada perlakuan ini adalah 6,45 menit. Berdasarkan hasil pencacahan daun cengkeh yaitu perlakuan cacahan besar didapatkan 2 rendemen bahan yang terdiri dari daun cacahan besar sebesar $61,67 \%$ dan daun cacahan kecil sebesar 35\% dengan total persentase kehilangan 3,33\%. Waktu total yang dibutuhkan untuk menghasilkan cacahan besar mulai dari pencacahan hingga pengayakan adalah 19,04 menit setiap ulangan.

Waktu yang dibutuhkan untuk mencacah pada perlakuan cacahan kecil adalah 15,11menit dan waktu yang dibutuhkan untuk mengayak pada perlakuan ini adalah 4,18 menit. Pada perlakuan cacahan kecil didapatkan 2 rendemen bahan pula yang terdiri dari daun cacahan besar sebesar 30,83\% dan daun cacahan kecil sebesar $65,28 \%$ dengan total persentase kehilangan 3,89\%. Waktu total yang dibutuhkan untuk menghasilkan cacahan kecil mulai dari pencacahan hingga pengayakan adalah 19,29 menit setiap ulangan.

Tabel 3. Hasil Pencacahan Daun Cengkeh Perlakuan Cacahan Kecil dengan 3 Kali Pencacahan

Table 3. The Result of The Cutting on Clove Leaves of Small Cut Leaves Treatment WithThrice Cutting

$$
\text { Total }
$$

\begin{tabular}{ccc}
$\begin{array}{c}\text { Cacahan } \\
\text { Cutting }\end{array}$ & $\begin{array}{c}\text { Rendemen } \\
\text { Yield }\end{array}$ & $\begin{array}{c}\text { Kehilangan } \\
\text { Total of } \\
\text { Loss }\end{array}$ \\
\hline $\begin{array}{c}\text { Besar } \\
\text { Big }\end{array}$ & $30,83 \%$ & $3,89 \%$ \\
Kecil & $65,28 \%$ & \\
Small & & \\
\hline
\end{tabular}

Rendemen pada perlakuan cacahan kecil lebih besar daripada rendemen pada perlakuan cacahan besar karena daun yang dicacah dengan mesin akan terjadi kehilangan bahan oleh panas dari mesin tersebut mengakibatkan banyak yang menjadi cacahan lebih kecil lagi bahkan menjadi debu dan menempel pada bagian dalam mesin pencacah. Setiap selesai pencacahan dalam 1 ulangan, bagian dalam mesin pencacah akan dibuka untuk mengambil hasil cacahan yang masih menempel pada bagian dalam mesin. Saat dilakukan pengayakan pada bahan tersebut, dapat dipastikan cacahan yang menempel pada mesin lolos ayakan 4 mesh atau termasuk dalam bahan cacahan kecil.

Berdasarkan hasil yang didapatkan pada masing-masing perlakuan memiliki efisiensi dengan selisih antara cacahan besar dan cacahan kecil tidak terlalu besar yakni sebesar $3,61 \%$ dan 25 detik. Jika ditinjau dari rendemen bahan yang dihasilkan, waktu yang dibutuhkan serta hasil minyak setelah penyulingan, maka perlakuan terbaik adalah cacahan kecil. 


\section{WarnaMinyak}

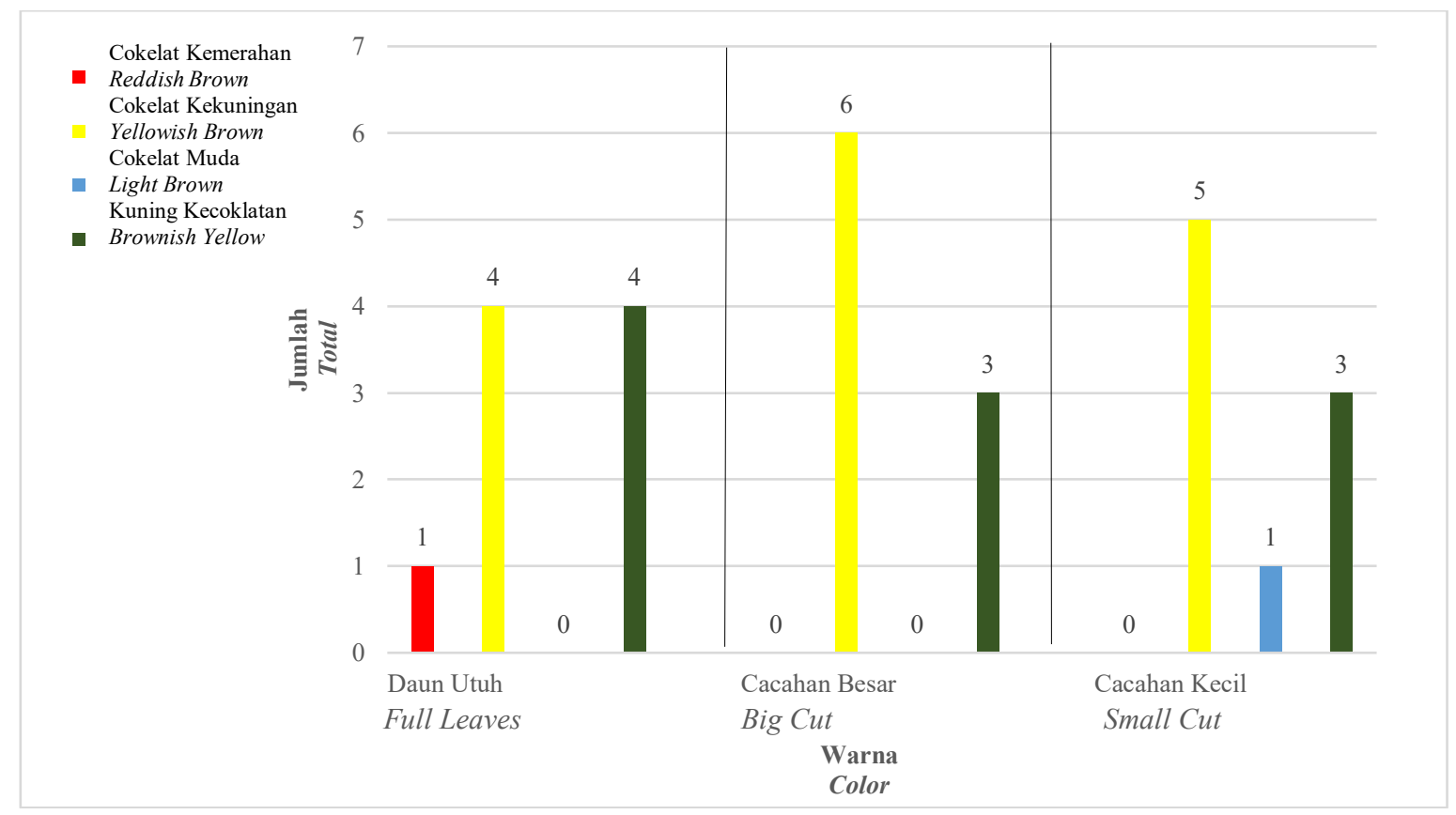

Gambar 1. Warna yang Dihasilkan dari Masing-Masing Perlakuan Minyak Daun Cengkeh pada 2 Minggu Setelah Penyulingan

Figure 1. The Colors resulted from Each Treatment of Clove Leaf Oil at Two Weeks After Distilation

SNI minyak daun cengkeh adalah kuning hingga cokelat tua. Berdasarkan gambar 1 pada perlakuan daun utuh menghasilkan warna cokelat kemerahan dengan total 1 sampel atau ulangan, 4 ulangan warna cokelat kekuningan, dan 4 ulangan warna kuning kecokelatan. Pada perlakuan cacahan besar menghasilkan 6 ulangan warna cokelat kekuningan dan 3 ulangan warna kuning kecokelatan. Pada perlakuan cacahan kecil menghasilkan 5 ulangan cokelat kekuningan, 1 ulangan cokelat muda, dan 3 ulangan kuning kecokelatan.

Warna minyak daun cengkeh merupakan salah satu parameter yang harus dipenuhi karena termasuk dalam penentuan kualitas. Mutu minyak daun cengkeh terutama ditentukan oleh kandungan eugenol dan warna minyak. Perbedaan pencacahan tidak berpengaruh terhadap warna minyak daun cengkeh karena jumlah warna terbanyak yang dihasilkan pada masing-masing perlakuan sama yaitu cokelat kekuningan dan pada daun utuh jumlah terbanyak selain cokelat kekuningan adalah kuning kecokelatan.

Warna minyak daun cengkeh akan semakin gelap hingga hitam kecokelatan karena terdapat ion-ion logam yang bereaksi dengan senyawa terutama eugenol dalam minyak tersebut. Logam tersebut dapat berasal dari daun cengkeh atau alat penyuling tersebut. Pada minyak daun cengkeh terdapat logam-logam $\mathrm{Mg}, \mathrm{Mn}$, $\mathrm{Fe}$, dan $\mathrm{Pb}$. Penyerapan logam dari tanah kemudian ke akar serta penyerapan logam dari udara melalui stomata (Marwati, Meika and Edy, 2007). Perbedaan warna pada masing-masing perlakuan dikarenakan pula oleh kondensat yang tercampur oleh kotoran menyebabkan minyak menjadi kotor dan gelap serta masih tercampur air.

Biasanya kotoran ini akan menempel pada dinding-dinding pipa kondensor atau terbawa dalam botol penampung saat penyulingan berlangsung menjadi satu 
dengan kondensat. Setelah penyulingan selesai akan dilakukan penyemprotan dengan kompresor sehingga kotoran, minyak, dan air yang masih menempel pada kondensor ikut terbawa ke dalam kondensat. Pemisahan minyak pada kondensat menggunakan separator kurang baik dan maksimal. Kemungkinan kotoran tercampur dan mengendap bersama minyak menjadi besar karena minyak daun cengkeh termasuk minyak berat dengan berat jenis minyak daun cengkeh adalah $>1$.

\section{Kadar Eugenol}

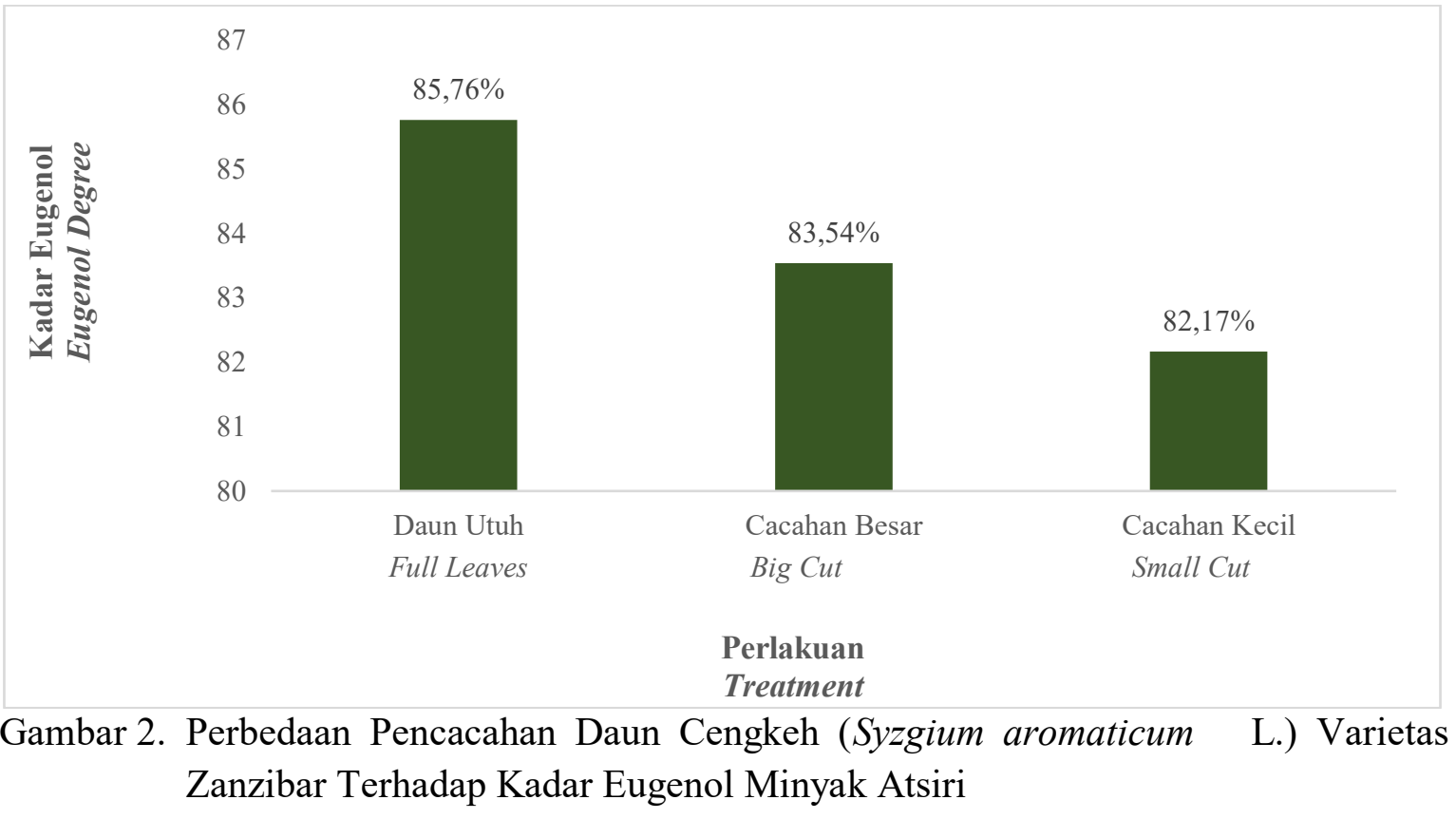

Figure 2. The Difference of The Cutting on Zanzibar clove leaves and the Eugenol production.

SNI kadar eugenol minyak daun cengkeh adalah minimal $78 \%$. Berdasarkan uji Gas Chromatography yang telah dilakukan didapatkan rata-rata kadar eugenol yang tertera pada Gambar 2 menunjukkan bahwa kadar eugenol tertinggi adalah daun utuh dengan persentase $85,76 \%$, cacahan besar memiliki persentase $83,54 \%$, dan kadar eugenol terendah yaitu cacahan kecil dengan persentase $82,17 \%$. Ketiga perlakuan sudah memenuhi dan melebihi dari standar yang ditetapkan serta membuktikan bahwa kadar eugenol tertinggi adalah minyak daun cengkeh Varietas Zanzibar.
Hasil pengamatan pada parameter ini menyatakan bahwa pencacahan berpengaruh terhadap kadar eugenol. Hal ini sesuai dengan pernyataan Ketaren (1985) dan Guenther (1990) bahwa perlakuan awal yaitu pencacahan pada bahan yang akan dilakukan penyulingan menghasilkan minyak daun cengkeh dengan kadar eugenol yang lebih rendah daripada daun yang masih utuh karena dengan adanya pencacahan maka kelenjar minyak akan terbuka sebanyak mungkin dan terjadi penguapan minyak atsiri serta komponen kimia pada minyak tersebut saat bahan setelah dicacah sebelum penyulingan. 
Faktor lain yang mempengaruhi kadar eugenol adalah ketinggian tempat. Semakin tinggi tempat tumbuh maka semakin rendah kandungan eugenol. Ketinggian tempat pengambilan daun cengkeh adalah \pm 500 mdpl masih tergolong dataran menengah sehingga kadar eugenol yang diperoleh masih tinggi dan melampaui standar. Perlakuan terbaik untuk menghasilkan kadar eugenol yang tinggi namun ditinjau dengan rendemen minyak yang dihasilkan adalah perlakuan dengan cacahan kecil.

\section{Uji Kuantitatif}

Tabel 4. Rekapitulasi Anova Parameter Kuantitatif

Table 4. The Recapitulation of Anova Quantitative Parameter

\begin{tabular}{|c|c|c|c|c|c|c|}
\hline \multirow[b]{2}{*}{ SK } & \multirow[b]{2}{*}{$\mathrm{Db}$} & \multicolumn{4}{|c|}{ F Hit } & \multirow[b]{2}{*}{ F Tab } \\
\hline & & $\begin{array}{c}\text { Kadar Air } \\
\text { Water } \\
\text { Degree }\end{array}$ & $\begin{array}{c}\text { Volume } \\
\text { Minyak } \\
\text { Oil Volume }\end{array}$ & $\begin{array}{c}\text { Berat } \\
\text { Minyak } \\
\text { Oil Weight }\end{array}$ & $\begin{array}{l}\text { Rendemen } \\
\text { Minyak } \\
\text { Oil Yield }\end{array}$ & \\
\hline $\begin{array}{l}\text { Ulangan } \\
\text { Repeat }\end{array}$ & 8 & $7,38 * *$ & $5,82 * *$ & $5,04 * *$ & $5,04 * *$ & $\begin{array}{l}2,59^{5 \%} \\
3,89^{1 \%}\end{array}$ \\
\hline $\begin{array}{l}\text { Perlakuan } \\
\text { Treatment }\end{array}$ & 2 & $21,77 * *$ & $98,62 * *$ & $88,01 * *$ & $88,01 * *$ & $\begin{array}{l}3,63^{5 \%} \\
6,23^{1 \%} \\
\end{array}$ \\
\hline $\begin{array}{l}\text { Galat } \\
\text { Error } \\
\text { Total } \\
\text { Total }\end{array}$ & $\begin{array}{l}16 \\
26\end{array}$ & & & & & \\
\hline $\begin{array}{l}\text { Koefisien } \\
\text { Keragaman }\end{array}$ & & $11,71 \%$ & $41,66 \%$ & $43,15 \%$ & $13,65 \%$ & \\
\hline
\end{tabular}

\section{Kadar Air Bahan}

Tabel 5. Rata-Rata Kadar Air Daun Cengkeh Pada Setiap Perlakuan

Table 5. The Water Contain of Clove Leaves in Each Treatment

\begin{tabular}{lc}
\hline $\begin{array}{l}\text { Perlakuan } \\
\text { Treatment }\end{array}$ & $\begin{array}{c}\text { Rata-Rata } \\
\text { Average }\end{array}$ \\
\hline Daun Utuh & $14,16 \%$ \\
Full Leaves & \\
Cacahan Besar & $13,29 \%$ \\
Big Cut & \\
Cacahan Kecil & $12,85 \%$ \\
Small Cut & \\
\hline
\end{tabular}

Saat akan dilakukan pencacahan, daun cengkeh tersebut memiliki kadar air $\pm 15 \%$ karena daun yang jatuh tersebut sudah kering. Pengeringan ini bertujuan untuk menghomogenkan kadar air dari daun cengkeh tersebut. Lepasnya air dari daun cengkeh mengakibatkan sebagian uap air yang ada dalam bahan akan menguap dan meninggalkan ruang kosong serta selsel minyak pecah yang akhirnya memudahkan pengambilan minyak selama penyulingan. Berdasarkan rata-rata yang didapatkan pada Tabel 5 menunjukkan bahwa tanpa perlakuan atau daun utuh, memiliki kadar air tertinggi yaitu 14,16\% sedangkan kadar air terendah yaitu perlakuan cacahan kecil dengan rata-rata persentase $12,85 \%$. Hasil uji lanjut kontras ortogonal pada tabel 6 menunjukkan bahwa antara perlakuan daun utuh dan daun cacahan berbeda sangat nyata 
sedangkan antara perlakuan cacahan besar dan cacahan kecil berbeda nyata. Hal ini berarti bahwa pencacahan yang dilakukan menghasilkan ukuran bahan yang berbeda yaitu cacahan besar dan cacahan kecil mempengaruhi persentase kadar air masing-masing perlakuan.

Pencacahan menyebabkan kadar air berkurang. Semakin kecil cacahan maka kadar air yang terkandung di dalam daun cengkeh akan semakin berkurang karena bagian dalam daun yang terkena udara luar semakin banyak dan mengakibatkan mudahnya air menguap. Selain itu, dengan adanya pengeringan sebelum pencacahan, air pada daun cengkeh tersebut akan teruapkan saat pengeringan yang akan berdampak pada dinding sel membran akan mengkerut kemudian pecah. Pada kondisi seperti ini, uap air akan mudah untuk berpenetrasi sehingga minyak yang terdapat di dalam daun akan teruapkan dengan optimal.
Menurut Guenther (2011) bahan yang akan dilakukan penyulingan apabila memiliki kadar air yang tinggi menyebabkan penyulingan tidak sempurna. Selain itu, kadar air yang terlalu tinggi menyebabkan daun cengkeh mudah terserang jamur sebelum dilakukan penyulingan yang dapat mempengaruhi kuantitas atau rendemen minyak menjadi sedikit serta kualitas minyak yang dihasilkan akan jelek. Saat penyulingan berlangsung akan menyulitkan proses hidrodistilasi. Hal ini juga mempengaruhi daya simpan daun cengkeh sebelum dilakukan penyulingan. Namun jika kadar air daun cengkeh terlalu rendah di bawah $10 \%$ maka daun cengkeh akan mudah hancur sehingga penguapan yang terjadi akan lebih besar dan berakibat pada kehilangan minyak yang lebih banyak.

Tabel 6. Hasil Uji Lanjut Kadar Air Daun Cengkeh dengan Kontras Ortogonal

Table 6. The Result of Advanced Test of Water Degree of Clove Leaves With Orthogonal Contrast

\begin{tabular}{|c|c|c|c|}
\hline $\begin{array}{l}\text { Komponen } \\
\text { Component }\end{array}$ & $\begin{array}{l}\text { Kontras } \\
\text { Contrast }\end{array}$ & F Hit & F Tab \\
\hline 1 & $\begin{array}{l}\text { Daun Utuh Vs Daun Cacahan } \\
\text { Full Leaves vs Cut Leaves }\end{array}$ & $38,77 * *$ & $\begin{array}{l}4,495 \% \\
8,531 \%\end{array}$ \\
\hline 2 & $\begin{array}{l}\text { Cacahan Besar Vs Cacahan Kecil } \\
\text { Big Cut vs Small Cut }\end{array}$ & $4,78^{*}$ & $\begin{array}{l}4,495 \% \\
8,531 \%\end{array}$ \\
\hline
\end{tabular}

Berdasarkan hasil tersebut, pencacahan terbaik adalah cacahan kecil mengacu pada rendemen minyak dan kadar air yang dimiliki tidak terlalu tinggi atau melebihi standar yaitu $16 \%$ dan tidak di bawah $10 \%$.

\section{Volume Minyak}

Berdasarkan rata-rata yang didapatkan pada Tabel 7, volume minyak tertinggi yakni pada perlakuan cacahan kecil dengan rata-rata $34,18 \mathrm{ml}$, perlakuan cacahan besar 28,57 $\mathrm{ml}$, serta volume terendah yaitu perlakuan daun utuh sebesar $19,82 \mathrm{ml}$.

Adanya perlakuan awal yaitu pencacahan membuat kantung minyak akan terbuka sebanyak mungkin karena penguapan, sehingga minyak atsiri yang terdapat di dalam ruang antar sel dalam jaringan pada kantung minyak daun cengkeh dapat dengan mudah keluar dan diuapkan. 
Tabel 7. Rata-Rata Volume Minyak Daun Cengkeh Pada Setiap Perlakuan Yang Dihasilkan dari $1 \mathrm{~kg}$ Daun Cengkeh

Table 7. The Average Volume of Clove Leaf Oil in Each Tretment extracted from $1 \mathrm{~kg}$ of Clove Leaves

\begin{tabular}{lc}
\hline $\begin{array}{l}\text { Perlakuan } \\
\text { Treatment }\end{array}$ & $\begin{array}{c}\text { Rata-Rata } \\
\text { Average }\end{array}$ \\
\hline $\begin{array}{l}\text { Daun Utuh } \\
\text { Full Leaves }\end{array}$ & $19,82 \mathrm{ml}$ \\
Cacahan Besar & $28,57 \mathrm{ml}$ \\
Big Cut & \\
Cacahan Kecil & $34,18 \mathrm{ml}$ \\
Small Cut & \\
\hline
\end{tabular}

Berdasarkan hasil uji kontras ortogonal pada Tabel 8 menunjukkan bahwa antar perlakuan berbeda sangat nyata. Semakin kecil cacahan semakin tinggi volume minyak. Hal ini berarti bahwa pencacahan yang dilakukan menghasilkan ukuran bahan yang berbeda yaitu cacahan besar dan cacahan kecil mempengaruhi volume minyak dari masing-masing perlakuan.

Daun yang telah dicacah maka volume daun di dalam ketel suling lebih homogen, merata, dan tidak terlalu padat. Hal tersebut memudahkan jalannya proses hidrodifusi. Cacahan yang terlalu halus akan mengakibatkan bahan terlalu padat dalam ketel sehingga terjadi penggumpalan yang menyulitkan uap panas untuk berhidrodifusi. Berdasarkan hasil yang didapatkan, perlakuan terbaik adalah daun cacahan kecil karena menghasilkan volume minyak daun cengkeh tertinggi.

Tabel 8. Hasil Uji Lanjut Volume Minyak Daun Cengkeh dengan Kontras Ortogonal

Table 8. The Result of Advanced Test of Volume of Clove Leaf Oil With Orthogonal Contrast

\begin{tabular}{clcc}
\hline $\begin{array}{c}\text { Komponen } \\
\text { Component }\end{array}$ & \multicolumn{1}{c}{$\begin{array}{c}\text { Kontras } \\
\text { Contrast }\end{array}$} & F Hit & F Tab \\
\hline \multirow{2}{*}{1} & Daun Utuh Vs Daun Cacahan & \multirow{2}{*}{$167,57^{* *}$} & $4,495 \%$ \\
& Full Leaves vs Cut Leaves & & $8,531 \%$ \\
\cline { 3 - 3 } 2 & Cacahan Besar Vs Cacahan Kecil & \multirow{2}{*}{$29,66^{* *}$} & $4,495 \%$ \\
& Big Cut vs Small Cut & & $8,531 \%$ \\
\hline
\end{tabular}

Keterangan : ** = Berbeda sangat nyata pada taraf $1 \%$

Note : $* *=$ Very significantly different at the $1 \%$ level

\section{Berat Minyak}

Tabel 9. Rata-Rata Berat Minyak Daun Cengkeh Pada Setiap Perlakuan Yang Dihasilkan dari $1 \mathrm{~kg}$ Daun Cengkeh

Table 9. The Average Weight of Clove Leaf Oil in Each Tretment Extracted from $1 \mathrm{~kg}$ of Clove Leaves

\begin{tabular}{lc}
\hline $\begin{array}{l}\text { Perlakuan } \\
\text { Treatment }\end{array}$ & $\begin{array}{c}\text { Rata-Rata } \\
\text { Average }\end{array}$ \\
\hline Daun Utuh & 19,42 gram \\
Full Leaves & \\
Cacahan Besar & 28,17 gram \\
Big Cut & \\
Cacahan Kecil & 33,27 gram \\
Small Cut & \\
\hline
\end{tabular}

Berat minyak daun cengkeh dipengaruhi oleh volume minyak itu sendiri. Semakin tinggi volume minyak maka berat minyak akan semakin besar. Berdasarkan rata-rata yang didapatkan pada Tabel 9 rata-rata berat minyak terbesar adalah perlakuan cacahan kecil dengan berat 33,27 gram, cacahan besar 28,17 gram, dan berat minyak terkecil yakni perlakuan daun utuh dengan 19,42 gram. 
Tabel 10. Hasil Uji Lanjut Berat Minyak Daun Cengkeh dengan Kontras Ortogonal Table 10. The Result of Advanced Test of Weight of Clove Leaf Oil With Orthogonal Contrast

\begin{tabular}{clcc}
\hline $\begin{array}{c}\text { Komponen } \\
\text { Component }\end{array}$ & \multicolumn{1}{c}{$\begin{array}{c}\text { Kontras } \\
\text { Contrast }\end{array}$} & F Hit & F Tab \\
\hline \multirow{2}{*}{1} & Daun Utuh Vs Daun Cacahan & \multirow{2}{*}{$152,74^{* *}$} & $4,495 \%$ \\
& Full Leaves vs Cut Leaves & & $8,531 \%$ \\
\cline { 2 - 3 } 2 & Cacahan Besar Vs Cacahan Kecil & \multirow{2}{*}{$23,28^{* *}$} & $4,495 \%$ \\
& Big Cut vs Small Cut & $8,531 \%$ \\
\hline
\end{tabular}

Keterangan : ** $=$ Berbeda sangat nyata pada taraf $1 \%$ Note : $* *=$ Very significantly different at the $1 \%$ level

Berdasarkan hasil uji kontras ortogonal pada Tabel 10 menunjukkan bahwa antar perlakuan berbeda sangat nyata. Semakin kecil cacahan semakin besar berat minyak daun cengkeh yang didapatkan. Hal Ini berarti bahwa pencacahan yang dilakukan menghasilkan ukuran bahan yang berbeda yaitu cacahan besar dan cacahan kecil mempengaruhi berat minyak dari masing-masing perlakuan.

Daun yang telah tercacah dan lolos ayakan 4 mesh mampu meningkatkan volume minyak yang berdampak baik pada

\section{Rendemen Minyak}

Berdasarkan rata-rata persentase yang didapatkan pada Tabel 11 menunjukkan bahwa rendemen minyak tertinggi yaitu perlakuan cacahan kecil dengan persentase $3,33 \%$, cacahan besar $2,82 \%$, dan persentase rendemen terendah yaitu perlakuan daun utuh sebesar 1,94\%. Berdasarkan hasil uji kontras ortogonal pada Tabel 12 menunjukkan bahwa antar perlakuan berbeda sangat nyata. Semakin kecil cacahan semakin tinggi pula rendemen minyak daun cengkeh. Hal ini berarti bahwa pencacahan yang dilakukan menghasilkan ukuran bahan yang berbeda yaitu cacahan besar dan cacahan kecil mempengaruhi rendemen minyak dari masing-masing perlakuan. berat minyak karena dengan adanya perlakuan awal seperti pencacahan, maka akan menambah luas permukaan bahan atau daun cengkeh yang kontak dengan uap panas yang akan mempercepat proses hidrodifusi pada bahan tersebut dan mempercepat proses penyulingan sehingga minyak yang terekstrak atau dihasilkan akan lebih banyak (Khasanah et al, 2015). Perlakuan terbaik dari hasil yang didapatkan adalah perlakuan cacahan kecil karena menghasilkan berat minyak yang lebih besar daripada 2 perlakuan yang lain.

Tabel 11. Rata-Rata Rendemen Minyak Daun Cengkeh Pada Setiap Perlakuan Yang Dihasilkan dari $1 \mathrm{~kg}$ Daun Cengkeh

Table 11. The Average Yield of Clove Leaf Oil in Each Tretment Extracted from $1 \mathrm{~kg}$ of Clove Leaves

\begin{tabular}{lc}
\hline $\begin{array}{l}\text { Perlakuan } \\
\text { Treatment }\end{array}$ & $\begin{array}{c}\text { Rata-Rata } \\
\text { Average }\end{array}$ \\
\hline $\begin{array}{l}\text { Daun Utuh } \\
\text { Full Leaves }\end{array}$ & $1,94 \%$ \\
Cacahan & $2,82 \%$ \\
Besar & \\
Big Cut & $3,33 \%$ \\
Cacahan Kecil & \\
Small Cut & \\
\hline
\end{tabular}


Tabel 12. Hasil Uji Lanjut Rendemen Minyak Daun Cengkeh dengan Kontras Ortogonal

Table 12. The Result of Advanced Test of Yield of Clove Leaf Oil With Orthogonal Contrast

\begin{tabular}{clcc}
$\begin{array}{c}\text { Komponen } \\
\text { Component }\end{array}$ & \multicolumn{1}{c}{$\begin{array}{c}\text { Kontras } \\
\text { Contrast }\end{array}$} & F Hit & F Tab \\
\hline \multirow{2}{*}{1} & Daun Utuh Vs Daun Cacahan & \multirow{2}{*}{$152,65^{* *}$} & $4,495 \%$ \\
& Full Leaves vs Cut Leaves & & $8,531 \%$ \\
\hline \multirow{2}{*}{2} & Cacahan Besar Vs Cacahan Kecil & $23,22 * *$ & $4,495 \%$ \\
& Big Cut ss Small Cut & $8,531 \%$ \\
\hline
\end{tabular}

Keterangan : ** = Berbeda sangat nyata pada taraf $1 \%$

Note : $* *=$ Very significantly different at the $1 \%$ level

Sel atau kelenjar minyak pada daun banyak ditemukan pada jaringan parenkim bunga karang dan parenkim palisade (Jailani, Rudianda and Evi, 2015). Pengecilan ukuran daun memiliki efek menambah luas permukaan daun cengkeh sehingga minyak atsiri yang dihasilkan akan lebih banyak serta sebagian minyak atsiri akan mampu keluar permukaan daun dan segera menguap oleh uap panas, sebagian lagi dengan proses difusi akan muncul ke permukaan. Daun yang telah tercacah membuat proses difusi pada hidrodistilasi menjadi lebih cepat dan luas bidang sentuh antara daun cengkeh dengan uap lebih besar.

Pencacahan ini penting karena menurut Guenther (2011) dari hasil penyulingan menunjukkan bahwa minyak atsiri akan lebih banyak didapatkan apabila dinding sel nya dirusak. Pencacahan juga akan mempermudah dalam peletakannya di dalam ketel suling. Tingkat kepadatan bahan berhubungan erat dengan ruang antar bahan. Daun cengkeh pada perlakuan cacahan kecil tidak terlalu memenuhi ketel suling dan cacahan daun yang dihasilkan tidak terlalu halus atau terlalu kecil. Jika terlalu halus diantara bahan dalam ketel akan membentuk saluran uap (rat holes).

Banyak faktor selain pencacahan yang mempengaruhi rendemen seperti varietas, ketinggian tempat, keadaan daun, dan cara penyulingan. Varietas Zanzibar memiliki kandungan minyak lebih tinggi, keadaan daun baik, tidak berjamur, dan masih mengkilat atau berwarna kuning. Menggunakan metode penyulingan uap dan air karena minyak daun cengkeh tidak mudah rusak yang disebabkan oleh panas uap dan air. Rendemen juga dipengaruhi oleh hasil dari pengamatan parameter volume dan berat minyak. Semakin tinggi volume dan semakin besar berat minyak, maka persentase rendemen minyak daun cengkeh akan semakin tinggi pula.

Rendemen yang tinggi tanpa mutu yang baik akan kurang berguna. Parameter utama di dalam minyak daun cengkeh yaitu kadar eugenol serta sifat fisik yang terlihat lebih dulu yaitu warna karena dengan rendemen yang tinggi diimbangi dengan kadar eugenol yang tinggi pula serta warna minyak yang sesuai SNI akan menambah nilai jual dari minyak daun cengkeh tersebut. Perlakuan terbaik dari hasil yang didapatkan adalah perlakuan cacahan kecil karena menghasilkan rendemen minyak yang lebih tinggi daripada perlakuan daun utuh dan daun dengan cacahan besar.

\section{KESIMPULAN}

Perbedaan pencacahan daun kering cengkeh berpengaruh terhadap hasil minyak atsiri kecuali pada parameter warna. Perlakuan terbaik untuk menghasilkan rendemen minyak daun cengkeh tertinggi adalah perlakuan dengan cacahan kecil. 


\section{DAFTAR PUSTAKA}

Bustaman, S. (2011). Potensi 的 Pengembangan Minyak Daun Cengkeh sebagai Komoditas Ekspor Maluku. Jurnal Litbang Pertanian, 30(4), 132-139. https://doi.org/10.21082/jp3.v30n4.2 011.p132-139

Direktorat Jenderal Perkebunan. (2016). EStatistik Perkebunan Indonesia (2015-2017 Cengkeh).

Guenther. (1990). Minyak Atsiri Jilid IVB. 期 Jakarta: UI-Press.

Guenther, E. (2011). Minyak Atsiri Jilid 1. EQ Jakarta: UI-Press.

Jailani, A., Sulaeman, R., \& Sribudiani, E. (2015). Karakteristik Minyak Atsiri Daun Kayu Manis (Cinnamomum burmannii (Ness \& Th.Ness)). Jurnal Online Mahasiswa Fakultas Pertanian Universitas Riau, 2(2).

Ketaren. (1985). Pengantar Teknologi 皿 Minyak Atsiri. Jakarta: Balai Pustaka.

Khasanah, L. U., Kawiji, Utami, R., \& Aji, 毁 Y. M. (2015). Pengaruh Perlakuan Pendahuluan Terhadap Karakteristik Mutu Minyak Atsiri Daun Jeruk Purut (Citrus hystrix DC). Jurnal Aplikasi Teknologi Pangan, 4(2), 48-55.

Marwati, T., Rusli, M. S., \& Mulyono, E. E (2007). Pemucatan Minyak Daun Cengkeh Dengan Metode Khelasi Menggunakan Asam Sitrat. Jurnal of Agroindustrial Technology, 17(2), 61-68.

Perdana, Musthofa, \& Yusuf. (2015). Uji 尌 Performansi Unit Penyulingan Uap Daun Cengkeh Skala Laboratorium dengan Pretreatment Pencacahan Daun. Jurnal Keteknikan Pertanian Tropis Dan Biosistem, 3(3), 295302.

Rukmana, R., \& Yudirachman, H. (2016). Untung Selangit dari Agribisnis Cengkeh. Yogyakarta: Lily Publisher. 